\title{
Conflict in the Border Region Between Indonesia and Papua New Guinea
}

\author{
Usman Pakasi \\ The Islamic Education Foundation In Papua \\ Yapis Papua University \\ Papua, Indonesia \\ usmanpakasi@yahoo.com
}

\begin{abstract}
This research was aimed at identifying potential sources of conflict in the RI - PNG border territory, a case study in the Skow-Wutung border area, Muara Tami district, Jayapura city, Papua province. The study had been an in-depth analysis, using a qualitative approach, adopting the phenomenology strategy. Empirical data were obtained through in-depth interviews and observations. Results: potential sources of conflict in the Skow-Wutung (Indonesia - Papua New Guinea) border territory were identified as follows: indigenous land ownership (customary land) by PNG citizens on the Indonesian side of the border, illegal migrants and illegal trafficking, drugs and sharp weapons sales, double citizenships, illegal use of PNG currency on Indonesian side, operation of mototaxis and rickshaws by PNG citizens on Indonesian side, social and economic gaps (welfare), and lack of transportation facilities and infrastructures.
\end{abstract}

Keywords - conflict; border region; illegal migrants.

\section{INTRODUCTION}

Development in border territories is not just the central government's responsibility, but it also the duties of regional governments and citizens. The birth of the Special Autonomy Act [1] is one of the fundamental changes in governance in Papua; which was based on the central government's will to accelerate the improvement of Papuan citizens' welfare including those in Skow.

The development policy for border territories until now is still implemented on a sectoral basis; and ridden with conflicting interests. In several border territories many issues have emerged, especially concerning local citizens. From the economic perspective, the welfare of local citizens is generally saddening;forcing them to cross the border. From the political perspective, these illegal migrantsare motivated by extreme, anti-government groups that had fled to PNG. From the legal perspective, illegal migrants are subject to convictions under the law of the country they trespass illegally.

Border security has been one of the Indonesian government's priorities due to its relevance to the nation's sovereignty. Many issues arising on border territories that are difficult to resolve; such as illegal logging, drugs distribution, illegal trafficking, and illegal migration.

The Indonesia-Papua New Guinea border territory in Skow-Wutung is a crossing path of migration between citizens of the two countries. A number of issues identified as sources of conflict in the border territory of Skow-Wutung, Muara Tami district, Jayapura city are: (1) Indonesian illegal emigrants crossing into PNG territory and PNG illegal immigrants crossing into Indonesian territory not carrying official documents; (2) The areas surrounding the SkowWutung border territory are escape routes for individuals/groups wanted by law enforcers for criminal offences, as well as individuals who allegedly belong to organizations that oppose the sovereignty of the United Republic of Indonesia; (3) The border territory is prone to trafficking, especially of illegal substances (marijuana), and sharp weapons from outside Indonesia.

In addition to the issues mentioned above, infrastructure and facilities on the border territory are still lacking compared to other areas; depriving its local population of proper access to public needs and keeping their welfare low. Lack of access in the border territory is one of the factors that motivate its population to engage in socio-economic activities in the neighboring country, which on the long run is suspected to cause degradation in their nationalism. Difficult access to public services would motivate the population to interact more with citizens in the neighboring country. This problem has the potential of becoming a source of conflict between citizens of the two countries, as well as among the Indonesian citizens themselves. According to Wirawan [2], conflict is an opposition expressed between two or more parties in which each of the parties is dependent on the object of conflict and on patterns of behavior and interaction that breeds conflict.

Factors that cause conflict relate to the following: a population along with its aspects breeds pressure or conflict; existence of a number of elements that in principle contribute to disintegration or change of a system; all societies basing themselves on subjugation by some members of a society to other members [3].

Conflict analysis is accomplished by mapping said conflict. Miall, et al. [4] posit that conflict mapping is a method of presenting a given structural analysis at a given time. Moreover, Wehr and Baros [5] offer a technique of conflict mapping, consisting of specify the context; identify the parties; understand the dynamics; search for positive functions; and understand the regulation potential. 
The above illustrations justify the purpose of this research, that is to identify potential sources of conflict occurring in the Skow-Wutung border territory.

\section{RESEARCH METHODOLOGY}

The study had been an in-depth analysis, using a qualitative approach, adopting the phenomenology strategy. Empirical data were obtained through in-depth interviews and observations. This research was aimed at identifying potential sources of conflict in the RI - PNG border territory, a case study in the Skow-Wutung border area, Muara Tami district, Jayapura city, Papua province.

\section{RESEARCH FINDINGS \& DISCUSSION}

Identification of Potential Sources of Conflict in the SkowWutung Border Territory. Based on the problem and the purpose of this research, the author has identified a number of issues as potential sources of conflict in the RI-PNG border territory in Skow-Wutung village, Muara Tami district, Jayapura city as follows:

Custom land and indigenous rights

One of the problems that have become concerns for the Indonesian government in the Skow-Wutung border territory is indigenous land ownership (custom land). This problem arises due to some parts of land controlled by the government are claimed as indigenous lands belonging to PNG citizens. This is a complex issue because on one hand the lands are within Indonesian territory, while on the other hand indigenous land ownership is the right of PNG citizens. Every time the Indonesian government plans to build infrastructures on the lands, it is required to resolve this land ownership issues.

The indigenous land issues on the border territory do not only exist between the Indonesian government and PNG indigenous land owners, but also among Indonesian indigenous peoples - the responsibility of which falls into the provincial government. A number of indigenous land ownership issues in several villages surrounding the border territory have demanded attention from the Indonesian government.

Illegal Migration and Alternative Pathways

Illegal migrants on Skow-Wutung border territory is a serious problem. The intense emotional relationship between the two groups of population between Indonesia and PNG compels them to cross the border without following official procedures.

This emotional relationship derives from likenesses and similarities between the two peoples, such as culture and tradition, ethnic similarity, and family relations due to past marriages between clans. This condition compels the Indonesian and PNG governments to implement a joint policy to resolve the illegal migrations along the Skow-Wutung border.

The two governments have jointly issued special ID cards to replace passports and distributed them to local inhabitants of the border territory. Indonesian ID card holders are residents of the villages of Moso, Skow Sai, SkowYambe, and
Skow Mabo; while PNG card holders are residents of Vanimo city and Wutung village.

These ID cards issued by Indonesia and PNG only refer to citizens living on the border territory. They are only valid in the vicinity of Jayapura city in Papua province, Indonesia; and in Vanimo city and Wutung village in PNG. Should residents decide to travel abroad from points of departure outside the designated cities and villages, they are required to have passports.

Citizens who cross the border are required to obtain a permit from security officials stationed on the border. They are required to have a permit of entrance, in the form of either passports or the special ID cards. Migrants who cross the border without authorization from security officials are categorized as illegal migrants. Illegal migration occurs due to the many alternative pathways existing along the border, providing access from both land and sea; making it difficult for security officials of both countries to control traffic. These pathways are one of the main problems faced by the two countries.

Illegal migration is one of the main law offenses occurring on the border territory. This issue has significant potential to breed other criminal cases and sources of conflict, both vertical and horizontal. Criminal offenses such as drug traffickings and illegal sharp weapons are mostly related to illegal migrants. This was confirmed by one of the security officials assigned on the border; mentioning that several cases of drugs and sharp weapons trafficking have been found on illegal migrants.

Drugs and Sharp Weapons Trafficking

Illegal trafficking is a main cause for concern in the SkowWutung border territory. The entrance of illegal drugs and sharp weapons can be potential sources of conflict on the border territory. This issue is one of the government's main concerns; as confirmed by the Head of Border Agency [5], that indeed trafficking of sharp weapons and illegal substances such as marijuana still occur on the border territory. This issue arises from recent coordination meetings among stakeholders.

Criminal offenses like thefts and illegal substances trafficking, according to the Head of Border Agency are caused by the many alternative pathways through the forests. Illegal migrants also cross the border by sea, due to lack of control on the waters. This is also supported by the lack of proper function of the harbor, making it easier for criminal offenders to cross the border.

Responding to drug trafficking cases on the border territory has been a main concern for border security officials. The most recent case took place on 15 September 2015, in which officials from the Customs Supervision and Services Agency managed to intercept an attempt to smuggle $4 \mathrm{kgs}$ of shabu-shabu from PNG, estimated to worth IDR 4 billion.

Illegal trafficking of goods, especially drugs, according to border security officials often take place along the alternative pathways in the forests and by the sea, thus escaping their watch. Offenders move freely through the border via these alternative pathways, and transactions often happen on the sea, outside of security officers' reach. 


\section{Citizenship}

Another problem identified as a potential source of conflict is the citizenship issue. This problem is caused by citizens who frequently travel between the two countries have themselves registered as citizens in both countries (Indonesian and PNG).

In addition, as citizens they are entitled to universal coverages or insurance programs provided by both countries in accordance with their respective laws. This issue requires serious attention as it is a potential source of conflict.

\section{Mototaxis and Rickshaws}

Another cause for concern in Skow-Wutung border territory is the mototaxis and rickshaws operated by PNG citizens within Indonesian territory. The border market has been attracting increased activities of mototaxi drivers and rickshaw pullers. They profit significantly especially on market days. They provide transportation for people shopping on the market. They take PNG citizens from the borderline to the market and vice versa. The distance between the market and the borderline is approximately 300 meters.

The activity of these alternative means of transport attracts the attention of an Indonesian citizen living on the border territory. He suggested that most of the mototaxis are operated by PNG citizens in Indonesian territory, thus may cause problems if not anticipated properly. The PNG mototaxi drivers rent motorcycles from Indonesian citizens. They wear helmets painted with the PNG flag motif. Mototaxi drivers and rickshaw pullers freely sell their services to PNG citizens shopping in Indonesian territory. If the Indonesian government does not pay attention to this matter, it could become a potential source of conflict between citizens of the two countries.

Use of Foreign Currency

The border market has brought development and progress, but it has also cause issues particularly concerning the use of foreign currency in Indonesian territory. The currency being used in the market is the PNG's Kina.

The use of PNG currency on the border territory has been cause for concern for Indonesians living on the border territory. This is because the market is in Indonesia but the money used there is kina.The use of foreign currency on Indonesian soil would negatively affect the already plummeting value of the Indonesian Rupiah, which is far below the kina: 1 kina is 4,400 - 4,500 IDR.

Transportation

The border market in Skow-Wutung has brought development and progress in the transportation sector in the area. Construction of infrastructure and facilities in the border territory is taken seriously by the PNG government. It responds to its citizens' high purchasing interest by improving the transportation infrastructure and facility on the PNG side of the border.

The border transportation issue is not exclusive to people wishing to visit the border area, but is also faced by residents of the border territory. This was reported by one resident, who said that transportation was one of the main concerns for the local population.
Lack of transportation infrastructure and public transport facilities on the border territory has affected transportation costs. The high cost for transport is not worth the income earned, and thus affects the local population's welfare. Furthermore, lack of transportation infrastructure is one of the factors that has marginalized the village areas around the border territory, despite being part of Jayapura city.

Socio-economic Factor (Welfare)

Residents of the border territory are dominated by local inhabitants. Low level of welfare is one of the main issues faced by the local population. It is caused by the lack of infrastructure, low level of education and human resource quality, and limited health infrastructure and facility.

Lack of infrastructure and facilities on the border territory has contributed to the low rate of improvement in the quality of human resources in the area. This leads to the local population's inability to compete with other regions in terms of economy.

The development issues on the border territory has received a serious attention from the Papua provincial government. The Governor pledged to maximize the development in the Skow-Wutung border territory, considering it is one of the country's farthest outpost. Border territorial development demands serious attention from related stakeholders according to their respective duties and functions; such as the Directorate General of Specific Regional Development and Directorate General of Border Area Development of the Ministry of Development for Deprived Regions and Transmigration.

The governor's explanation is relevant to the researcher's observation regarding the problems faced by residents of Skow-Wutung village. They are in low welfare, contributed by lack of infrastructure and facilities, low income, low level of education, and lack of health services. The area is also isolated and marginalized, despite being part of Jayapura city.

The low welfare of the border territory population is caused by the following factors:

Production and income

The population's pattern of agriculture is still needsoriented, and not market-oriented. They also still produce limited harvests, barely sustaining their daily food needs. The low level of agricultural production contributes to low income.

The low agricultural production, according to an informant, is caused by the ineffective implementation of the capacity-building system by the government. Capacity building is not run effectively, leaving the local farmers to their traditional ways, keeping them oriented to sustaining daily needs.

Lack of economic sources in the border territory has brought a disparity of income between the local population and citizens in other areas. This disparity fuels social envy and is therefore a potential source of conflict. In addition, low welfare due to limited sources of income compels some of the local population to find work across the border. They consider it easier to get jobs in PNG than in Indonesia.

Border Market 
The market in Skow-Wutung border territory contributes to the region's development and progress. It was indeed designed to accelerate the local society's economic growth. The market is also utilized by PNG citizens.

The border market contributes significantly to economic activity due to the profits it generates for Indonesian vendors. According to the Head of Border Agency, the market can circulate up to 6 billion IDR worth of transactions a month. The types of goods sold in the market include groceries and electronics.

The locals' inability to compete in business could become a trigger for social envy and may lead to conflict.

\section{CONCLUSION}

Based on research results, a number of issues have been identified as potential sources of conflict in Skow-Wutung border territory. The issues are as follows: indigenous land owned by PNG citizens in Indonesian territory, alternative land- and sea paths, illegal migration and trafficking, drugs and sharp weapons trafficking, double citizenship, use of foreign currency (kina) on Indonesian territory, mototaxis and rickshaws operated by PNG citizens on Indonesian territory, socio-economic disparity (welfare), and lack of infrastructure and facilities.

Development in the border territory has brought positive effects on the local society's progress and welfare, but it has also contributed to new problems that are potential sources of conflict; either between the two governments or between the two populations living along the border.

\section{REFERENCES}

[1] Law of the Republic of Indonesia Number 21 of Year 2001. Special Autonomy for Papua Province, Papua Provincial Agency for National Unity: Jayapura.

[2] Wirawan. (2013). Leadership: Theory, Psychology, Organizational Behaviour, Application, and Research. PT. RajagrafindoPersada: Jakarta.

[3] Giddens, Anthony et. al. (2004). Sosiology, History and Ideas, translated into Indonesian by Ninik Rochani Syam. Kreasi Wacana: Yogyakarta.

[4] Mial, Hugh, Oliver Ramsbotham, and Tom Woodhouse. (2002). Peaceful Resolution of Contemporary Conflicts: Resolving, Preventing, and Changing Political, Religious, and Ethnic Conflicts (2 ${ }^{\text {nd }}$ Edition). PT. Raja GrafindoPersada: Jakarta.

[5] Susan, Novri, (2010). Introduction to Conflict Sociology and Contemporary Issues ( $2^{\text {nd }}$ Edition). Kencana:Jakarta. 